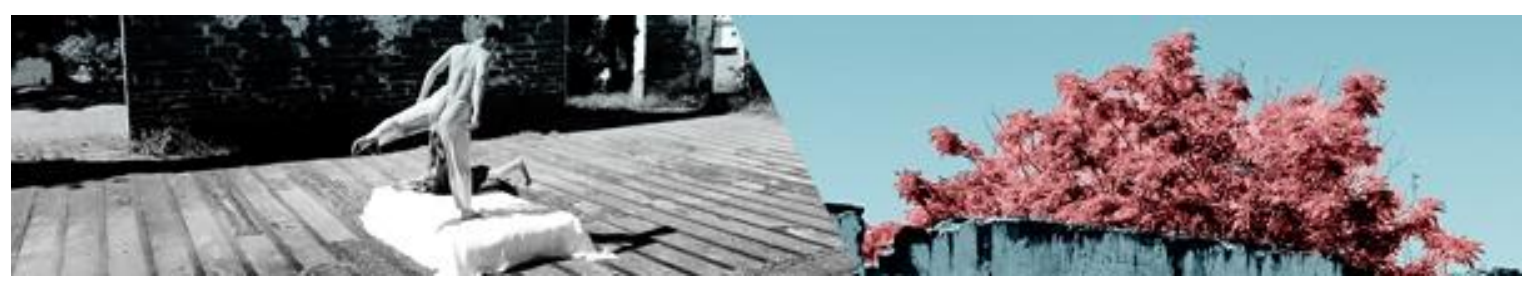

\title{
NOTAS SOBRE A TEATRALIDADE NA DANÇA-TEATRO DE PINA BAUSCH
}

Jeferson de Oliveira Cabral ${ }^{1}$

Vera Lúcia Bertoni dos Santos²

Resumo: Busca-se, neste artigo, além de resgatar e contextualizar aspectos da história da dançateatro desde seu surgimento até o momento em que Bausch adentra nesse cenário artístico, enfocar elementos presentes em cena na poética bauschiana a partir de premissas da "teatralidade" (Féral, 2004), conceito explorado nos estudos teatrais da atualidade.

Palavras-chave: Teatralidade; Dança-teatro; Performance; Pina Bausch; Cena contemporânea.

\section{NOTES ON THEATRICALITY IN DANCE-THEATER BY PINA BAUSCH}

Abstract: In this article we seek to rescue and contextualize aspects of the history of dance-theater from its inception to the moment in which Bausch enters this artistic scene, and to focus elements present in the scene in Bauschian poetry, based on premises of "theatricality" (Féral, 2004), concept explored in the theatrical studies of the present time.

Keywords: Theatricality; Dance-theater; Performance; Pina Bausch; Contemporary scene.

\section{Nota 1. Da dança-teatro de Pina Bausch}

Como tudo o que se inicia necessita de um preâmbulo, de uma ideia que se lapida, até virar palavra, frase, esta primeira nota apresenta um brevíssimo apanhado sobre as origens e o contexto mais amplo da dança-teatro, e propõe-se a situar o trabalho da bailarina e coreógrafa Pina Bausch (1940-2009) junto ao grupo de dança alemão Wuppertal Tanztheater, a partir dos elementos centrais que constituem o seu legado poético.

A formulação fundante do conceito de dança-teatro remete-se ao trabalho do bailarino, coreógrafo e teórico Rudolf Von Laban (1879-1958), profundo estudioso do movimento humano, precursor do chamado movimento criativo e considerado o pai da dança moderna. Ativista em favor da integração entre as artes e comprometido com o processo formativo e com a profissionalização dos seus bailarinos, Laban dedica-se à promoção do diálogo entre artistas de diversas áreas, deixando uma

\footnotetext{
1Jeferson de Oliveira Cabral é ator, bailarino e doutorando no Programa de Pós-Graduação em Artes Cênicas da Universidade Federal do Rio Grande do Sul (UFRGS). grandeje@gmail.com

2 Vera Lúcia Bertoni dos Santos é atriz, professora dra. associada e pesquisadora vinculada ao Programa de Pós-Graduação em Artes Cênicas (PPGAC) e ao Departamento de Arte Dramática (DAD) do Instituto de Artes da UFRGS. bertonica@gmail.com
}

CABRAL, Jeferson de Oliveira, SANTOS, Vera Lúcia Bertoni dos. Notas Sobre a Teatralidade na Dança-Teatro de Pina Bausch. Revista da FUNDARTE, Montenegro, p.19-31, ano 19, № 37, janeiro/Março.

Disponível em: http://.seer.fundarte.rs.gov.br/index.php/RevistadaFundarte/index> 30 de março de 2019. 


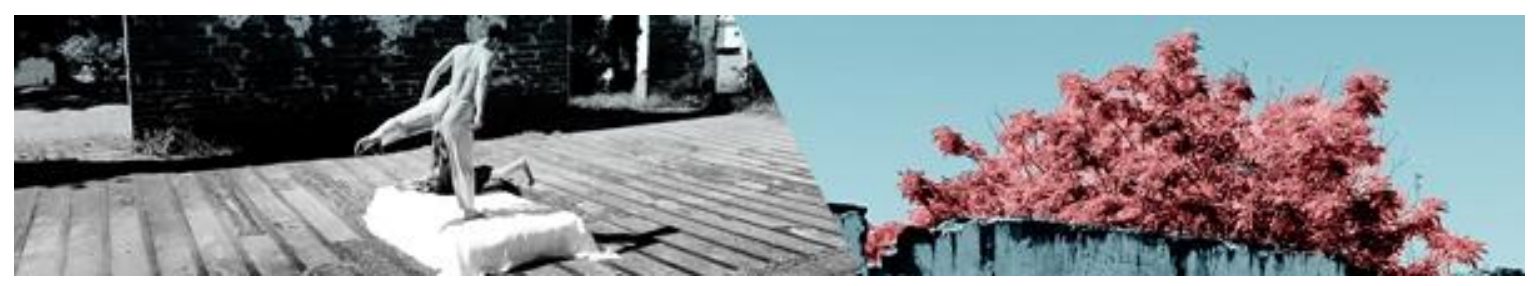

importante contribuição artística e pedagógica que se delineia a partir da década de 1920, inaugurando a concepção de um novo artista da dança.

Dentre as inúmeras contribuições desse artista da dança destaca-se a elaboração de um sistema pioneiro de "análise do movimento", a Labanotacion, e a disseminação de um trabalho comprometido com a pesquisa relacionada à corporeidade e à formação em dança em centros de investigação situados em diversos países da Europa.

O termo "dança-teatro", adotado por Laban, mas não precisamente delimitado em sua obra, relaciona-se, portanto, à maneira inovadora de como esse artista e seus seguidores mais diretos, dentre eles o bailarino, coreógrafo e professor Kurt Jooss (1901-1979), praticam e teorizam a dança: uma forma de arte que se desprende dos padrões da dança até então, que se desvincula da ideia de virtuosismo, que rompe com cânones de harmonia, temporalidade e espacialidade e com o compromisso com a expressão de sentimentos subjetivos, pautando-se pela exploração das possibilidades de movimento do corpo, numa ampla perspectiva que, além da própria dança, abarca o gesto, o movimento abstrato e os movimentos cotidianos.

Alinhada a essa concepção de dança surge a proposta de Pina Bausch junto do grupo alemão Wuppertal Tanztheater, que inicia suas atividades em 1973, caracterizado por uma bricolagem de formas artísticas que inclui a dança, o teatro e a performance. A fusão desses elementos é reflexo da formação artística eclética e multidisciplinar de Bausch, iniciada na década de 1950, na então Folkwang Hochsule, atual Folkawng University of the Arts (Essen, Alemanha). Nessa conceituada escola de dança, além do contato direto com Jooss e com a sólida e abrangente formação que lá se desenvolve, a jovem bailarina relaciona-se com diversos elementos artísticos. Outra experiência marcante na trajetória de Bausch ocorre na década de 1960, num intercâmbio de estudos na Juilliard School of Music, em Nova York, Estados Unidos, onde a performance passa a alcançar um grande público (GÁLHOS, 2010, p.60).

Ainda que de passagem, cabe considerar algumas ideias em relação à emergência do performer, bem como à noção de performance na cena 


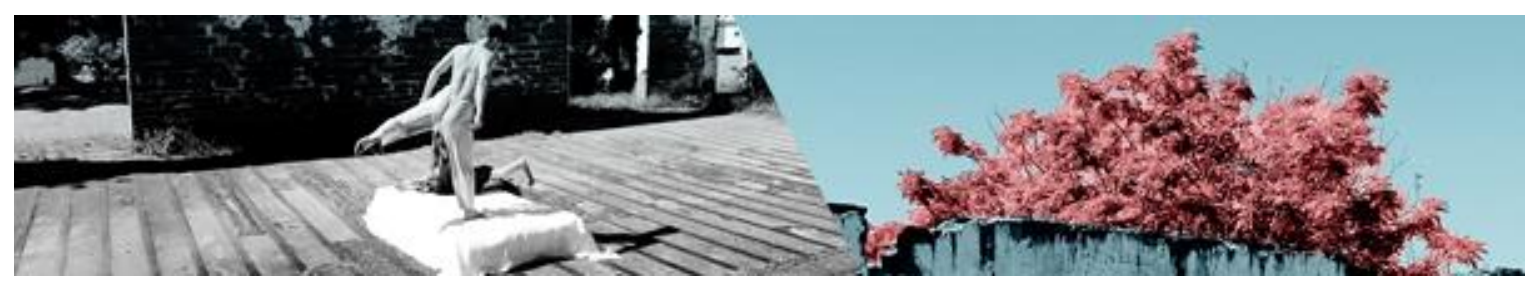

contemporânea, com base em definições pinçadas do Dicionário de Teatro de Patrice Pavis (1999) e em um estudo da pesquisadora Josette Féral (2008).

Conforme Pavis, o termo performer marca "a diferença em relação à palavra ator, considerada muito limitada ao intérprete do teatro falado" (PAVIS, 1999, p. 284), e caracteriza também o cantor, o bailarino, o músico e outro tipo de artista que realize "uma façanha (uma performance) vocal, gestual ou instrumental, por oposição à interpretação e à representação mimética do papel pelo ator" (PAVIS, 1999, p. 284). O performer "fala e age em seu próprio nome (enquanto artista e pessoa) e como tal se dirige ao público", realizando uma "encenação de seu próprio eu" (PAVIS, 1999, p. 284-285).

Ao caracterizar o chamado "teatro performativo", Féral (2008, p. 198) observa alguns elementos trazidos pela performance, dos quais $o$ teatro passa a beneficiarse, e que se manifestam com frequência e de diferentes formas na cena contemporânea:

[...] transformação do ator em performer, descrição dos acontecimentos da ação cênica em detrimento da representação ou de um jogo de ilusão, espetáculo centrado na imagem e na ação e não mais sobre o texto, apelo a uma receptividade do espectador de natureza essencialmente espetacular ou aos modos das percepções próprias da tecnologia[...] .(FÉRAL, 2008, p. 198).

Muitas razões levam a considerar as influências da performance na poética do Wuppertal, mas aqui se enfatiza a opção de Bausch por concretizar uma arte intimamente ligada a experiências pessoais dos bailarinos com quem trabalha. Essas experiências vividas, inscritas no corpo, constituem pontos de partida o levantamento de diversas problemáticas individuais e sociais que se fundem à dança, ao teatro e à performance, num processo de criação e questionamento. $\mathrm{A}$ proposta da coreógrafa faz dos artistas membros do Wuppertal Tanztheater o centro da reflexão, da dramaturgia e da execução das suas obras. Na construção dos seus espetáculos, Bausch interessa-se por compreender de que forma a sociedade é subjetivada nos corpos dos artistas do seu coletivo.

De acordo com Bentivoglio (1994, p.13), o início da carreira de Bausch como coreógrafa não se dá isento de indisposições por parte de membros do grupo, que se mostram resistentes às suas inusitadas propostas, negando-se a dar sequência a

CABRAL, Jeferson de Oliveira, SANTOS, Vera Lúcia Bertoni dos. Notas Sobre a Teatralidade na Dança-Teatro de Pina Bausch. Revista da FUNDARTE, Montenegro, p.19-31, ano 19, № 37, janeiro/Março.

Disponível em: http://.seer.fundarte.rs.gov.br/index.php/RevistadaFundarte/index> 30 de março de 2019. 


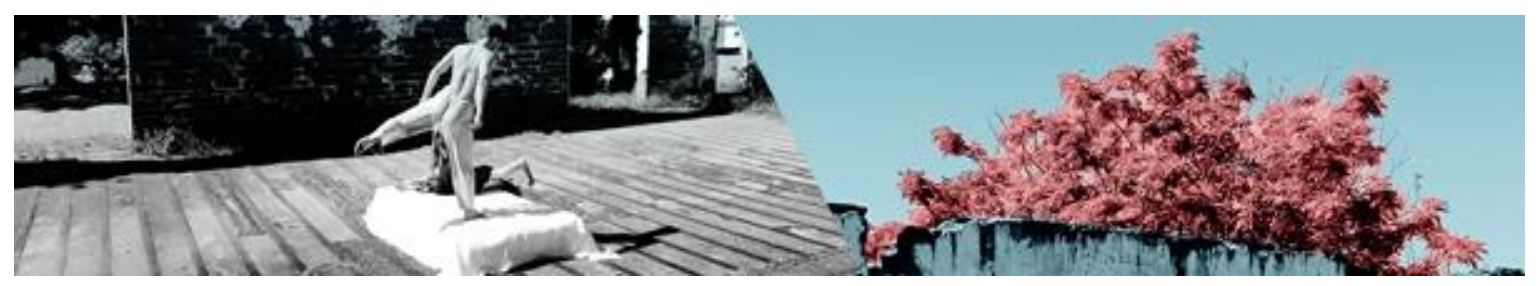

processos que a princípio lhes parecem inócuos. As maiores dificuldades localizamse justamente na perspectiva de exposição do "eu" desses bailarinos (acomodados a modos e processos tradicionais de dança), que implica acessar sentimentos, receios e desejos individuais e exige arriscar-se à experimentação de novas formas narrativas, como o gesto e a palavra.

A respeito do processo de formação do artista no coletivo dirigido por Bausch e das maneiras de como suas experiências de vida são postas em jogo no espaço de ensaio, a pesquisadora Leonetta Bentivoglio considera:

[...] um processo em que continuamente se desvenda a própria essência do indivíduo que faz teatro, para além de qualquer aspecto falsamente terapêutico. Não se faz "análise", mas nos defrontamos com os próprios sentimentos, ajustamos as contas com a própria verdade "como pessoa". (BENTIVOGLIO, 1994, p.28).

\section{Nota 2 - Da noção de teatralidade}

Os estudos sobre o que se convenciona chamar teatralidade decorrem da necessidade de abarcar a complexidade e a multiplicidade de manifestações do teatro contemporâneo, visto que tal noção parece permitir colocar em questão diálogos, atravessamentos e fusões de preceitos do teatro com a dança, a performance, a dança-teatro e outras artes artesanais, midiáticas ou intermediais que compõem a cena atual. Longe da necessidade de trazer certezas sobre um tema que se mostra complexo e de difíceis contornos, este estudo compreende a busca pelo entendimento da teatralidade, atrelada ao questionamento sobre a especificidade do teatro nesse contexto de amplas interações e rápidas transformações.

As reflexões dos estudiosos sobre 0 assunto não parecem revelar posicionamentos excludentes, ou seja, não parecem voltadas à normatização dos olhares sobre o que é ou não exclusivo do teatro, mas parecem querer identificar particularidades de cada forma de arte, especialmente daquelas que se realizam em interação direta, intencional ou não, com diferentes vertentes de teatro que se processam na atualidade.

CABRAL, Jeferson de Oliveira, SANTOS, Vera Lúcia Bertoni dos. Notas Sobre a Teatralidade na Dança-Teatro de Pina Bausch. Revista da FUNDARTE, Montenegro, p.19-31, ano 19, nํ37, janeiro/Março.

Disponível em: http://.seer.fundarte.rs.gov.br/index.php/RevistadaFundarte/index> 30 de março de 2019. 


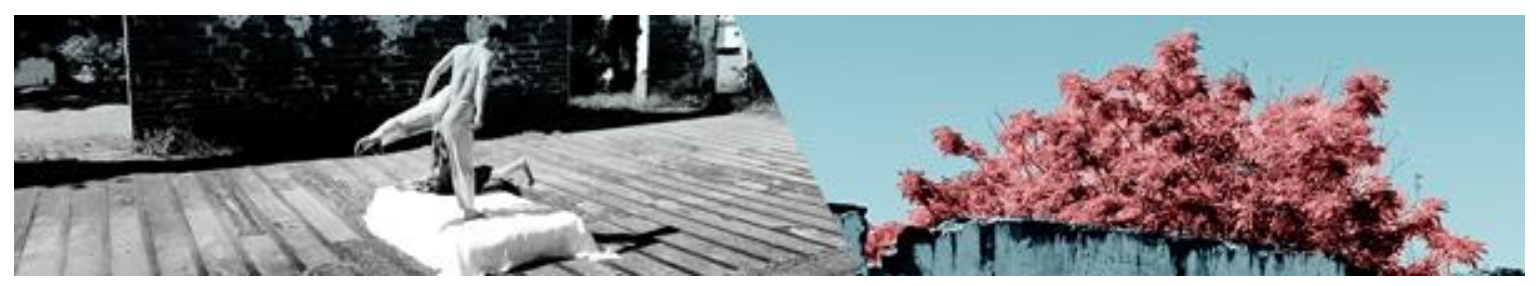

Para Féral (2004, p.87), "formular hoje o problema da teatralidade é buscar definir o que distingue o teatro de outros gêneros" (tradução nossa) ${ }^{3}$. Nessa perspectiva, identifica-se um esforço para que a história do teatro - vivida por diversos criadores e movimentos que o materializam em diferentes manifestações, através de distintos tempos e espaços e refletida por teóricos dedicados à análise e compreensão desse fenômeno estético e dos seus desdobramentos e contextos não se perca na interação com outras artes. Féral (2004) apresenta a sua argumentação mediante provocações ao seu leitor, através das quais se percebe 0 desejo de instalar um pensamento coletivo sobre o assunto, de fornecer pistas em busca do que é a teatralidade na arte contemporânea.

Ao que remete a teatralidade? Tal questão costuma levar o interlocutor leigo no assunto a pensar quem sabe na magia que o teatro propõe a quem se deixa adentrar a um espetáculo, na plasticidade dos signos ali presentes e, até mesmo, no aspecto amalgamado à presença cênica dos atores, no palco, ou de indivíduos em geral, que revelam especial desenvoltura ou histrionismo no cotidiano. Mas e o interlocutor mais avisado, leitor dos pressupostos de Féral e de outros teóricos dedicados ao assunto, de que forma compreende a teatralidade? É possível dizer que, da mesma maneira, as premissas da teatralidade formuladas pela autora dão respaldo, de certo modo, às colocações aparentemente mais ingênuas e desprovidas de sustentação teórica.

Na perspectiva de Féral (2004), a teatralidade acontece a partir do olhar que a materializa, do ponto de vista que, a partir de determinada ação, transforma o que vê em algo espetacular, construindo o sentido poético do que é visto como algo distinto, como algo teatral. A partir disso acontecem diversas reproduções de discursos que assimilam a teatralidade a episódios banais, triviais, a fatos cotidianos, não teatrais, que, por meio de relações perceptivas, tornam-se cênicos. Ou seja, segundo a autora, a questão do direcionamento do olhar é imprescindível para a compreensão da noção de teatralidade. Sob essa ótica:

\footnotetext{
3 "Formularse hoy el problema de la teatralidad es intentar definir lo que distingue al teatro de los otros géneros".
}

CABRAL, Jeferson de Oliveira, SANTOS, Vera Lúcia Bertoni dos. Notas Sobre a Teatralidade na Dança-Teatro de Pina Bausch. Revista da FUNDARTE, Montenegro, p.19-31, ano 19, № 37, janeiro/Março.

Disponível em: http://.seer.fundarte.rs.gov.br/index.php/RevistadaFundarte/index> 30 de março de 2019. 


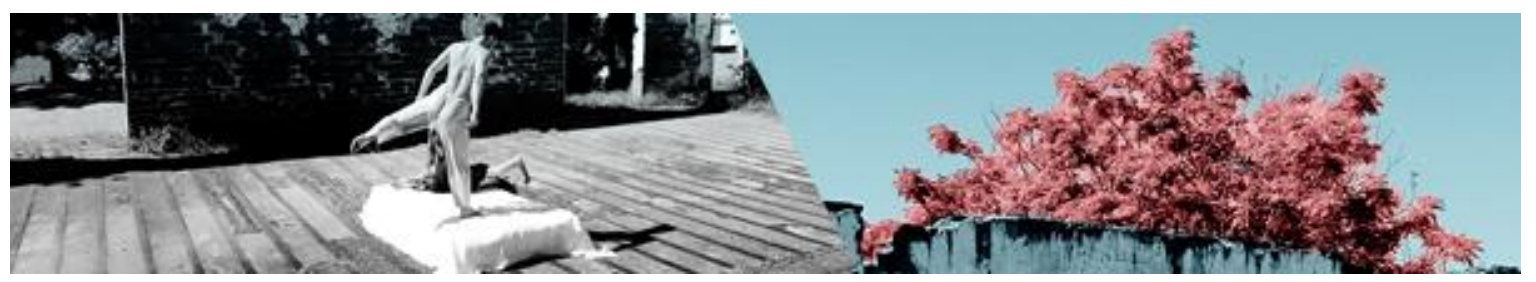

A condição para acontecer a teatralidade seria, então, a identificação (quando desejada pelo outro) ou a criação (quando o sujeito a projeta sobre as coisas) de um "espaço outro" do cotidiano. Um espaço que cria o olhar do espectador, mas fora do qual ele está. Esta divisão no espaço cria um fora e um dentro da teatralidade, que é o espaço do outro, que funda a alteridade da teatralidade. (FÉRAL, 2004, p.91) (tradução nossa) ${ }^{4}$.

Como se pode constatar, a premissa de Féral sobre a teatralidade confere poder ao olhar do espectador. É ele que, por sua própria decisão, cria um espaço que não é o real, pois está registrado no tempo do outro. O outro, nesse caso, é a pessoa, ou objeto em estado de performance, ou antes, algo que está em ação, que não pertence ao seu corpo.

Féral dedica-se a pensar na teatralidade do teatro quando se tem o espaço, o edifício, que gera a experiência teatral. Para isso, além do olhar do espectador, a pesquisadora ressalta a importância do corpo do ator, e da sua ação em si, pois a teatralidade pode ser provocada a partir da atuação. Essa ideia sugere que a teatralidade transcende o olhar, pois o corpo do ator apresenta sinas da sua produção. $\mathrm{O}$ ator consegue transformar tudo o que está à sua volta, através do olhar do espectador, consciente de que o mundo criado, embora fictício, é feito real pelo acordo entre esses dois pólos.

Os escritos de Féral enfocam também a ficção e a ilusão como efeitos da teatralidade. Para a autora, o espectador aceita a ideia de o que está em cena não é "real", pois a cena teatral tem por base a construção de tal artifício, como um acordo; ou seja, o público é convidado a embarcar na viagem que the é oferecida. A criação de um espaço e tempo outro é produzida por toda a equipe envolvida no espetáculo, representada no palco pelos atores e demais elementos que compõe a sua tessitura, como a cenografia, a iluminação, os recursos sonoros, dentre outros. Porém, a efetivação do evento teatral só ocorre em colaboração com quem o assiste, alguém

\footnotetext{
${ }^{4}$ La condición de la teatralidad sería, entonces, la identificación (cuando ella fue deseada por el otro) - la creación (cuando el sujeto la proyecta sobre las cosas) de un "espacio otro" del cotidiano, un espacio que crea la mirada del espectador, pero fuera del cual él permanece. Esta división en el espacio que crea un afuera y un adentro de la teatralidad es el espacio del otro. Es el fundador de la alteridad de la teatralidad.
}

CABRAL, Jeferson de Oliveira, SANTOS, Vera Lúcia Bertoni dos. Notas Sobre a Teatralidade na Dança-Teatro de Pina Bausch. Revista da FUNDARTE, Montenegro, p.19-31, ano 19, no 37, janeiro/Março.

Disponível em: http://.seer.fundarte.rs.gov.br/index.php/RevistadaFundarte/index> 30 de março de 2019. 


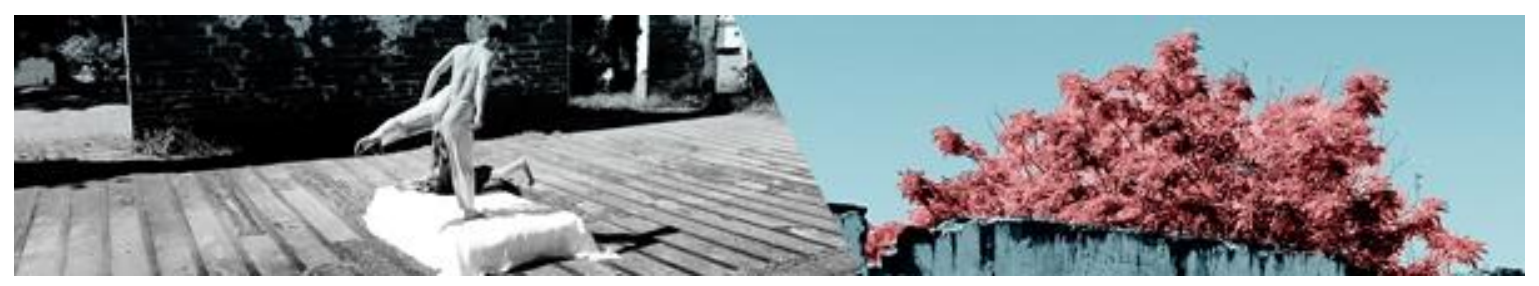

de fora da cena materializada, que cria o espaço ficcional de jogo entre os pólos da atuação e da expectação.

A teórica Silvia Fernandes (2010) expande a compreensão acerca da noção de teatralidade, ao abordar os elementos criados para a cena a partir do exemplo do teatro de Bertold Brecht (1898-1956), que influenciariam de forma decisiva as formas teatrais daquele momento em diante. Segundo ela, uma das intenções da poética brechtiana é expor a teatralidade ao público, através de "um mecanismo de revelação da teatralidade pelo próprio teatro" (FERNANDES, 2010, p.12), ou seja, trata-se de construir o espaço ficcional para desconstruí-lo e mostrar que a teatralidade é ali fabricada. Esses apontamentos sobre a ficção como algo a ser aceito possibilitam compreender o jogo de presença estabelecido em cena, entre os seus realizadores e aqueles que "se deixam" nela envolver, conferindo sentido à realidade que Ihes é apresentada.

A pensar na premissa que considera que o cerne da teatralidade está no jogo entre quem olha e quem é visto, infere-se que a discussão sobre teatralidade, aparentemente recente, delineia-se desde as formas fundantes do teatro e tende a fricções e ressignificações constantes. Independentemente do objeto estético, do tempo e do espaço em que se produza, independentemente do sujeito da mirada, dos seus "instrumentos de mediação" (seus conhecimentos prévios, seus sentimentos, emoções e estados de ânimo), a premissa central dos estudos de Féral, na qual esta reflexão se apoia, conduz ao entendimento que: “(...) a teatralidade aparece como a imbricação de uma ficção e uma representação de um espaço de alteridade que põe, frente a frente, um observador e um observado". (FÉRAL, 2004, p.100) (tradução nossa) ${ }^{5}$.

\section{Nota 3 - Dos vestígios de uma teatralidade mediada em Kontakthof}

Diante do exposto nas notas anteriores, cabe reconhecer que a tarefa de evidenciar a teatralidade de um objeto cênico não é simples; e a pensar no caso da obra de Bausch, que mescla seus elementos com extrema coesão e sobre a qual a

\footnotetext{
${ }^{5}$ No original: [...] la teatralidad aparece como la imbricación de una ficción en una representación en el espacio de una alteridad que pone frente a frente un observador y un observado.
}

CABRAL, Jeferson de Oliveira, SANTOS, Vera Lúcia Bertoni dos. Notas Sobre a Teatralidade na Dança-Teatro de Pina Bausch. Revista da FUNDARTE, Montenegro, p.19-31, ano 19, № 37, janeiro/Março.

Disponível em: http://.seer.fundarte.rs.gov.br/index.php/RevistadaFundarte/index> 30 de março de 2019. 


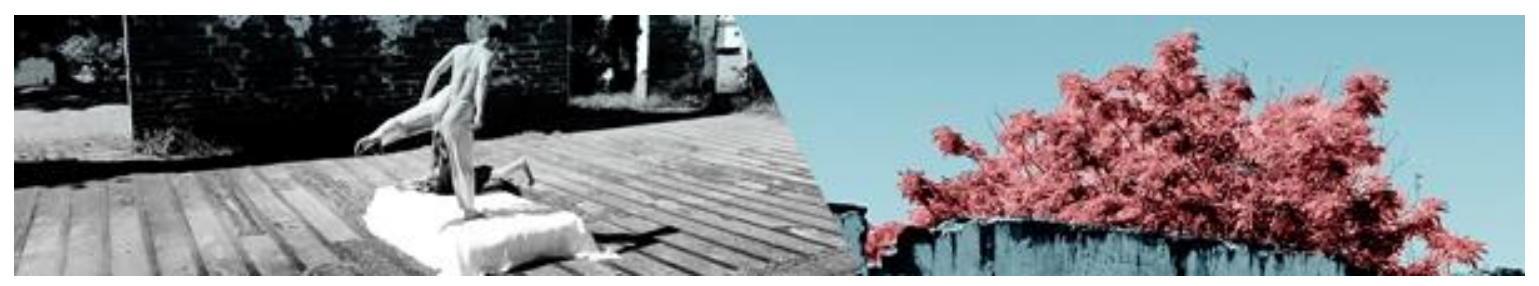

própria coreógrafa, nos seus depoimentos e entrevistas, não objetiva aspectos que possibilitem maiores inferências a respeito, ela torna-se ainda mais complexa - dirse-ia, arriscada - pois requer a busca de elementos que aqui se denominam "vestígios de teatralidade", cuja coleta é feita a partir de um olhar individual, um ponto de vista instrumentalizado, por certo, acurado, mas estritamente pessoal e, logo, passível de questionamento.

Esses vestígios são identificados mais especificamente em algumas das cenas do espetáculo Kontakthof (1978), em duas diferentes montagens, documentadas nos filmes "Pina" (2011), de Wim Wenders, e "Sonhos em Movimento" (2010), de Anne Linsen e Rainer Hoffman, ou seja, não são captados pelo olhar direto do espectador à cena, mas se fazem mediados, atravessados pelos enquadramentos, lentes e cortes dos realizadores dessas produções cinematográficas.

Kontakthof, do alemão "pátio de contatos" ou "lugar de contatos", aborda o tema da incompletude relacional: os afetos e relações humanas que nunca se completam; encontros que se chocam ao vento, mas que seguem seu rumo desprezando o contato, às vezes amoroso. $\mathrm{O}$ espetáculo mostra, de forma sutil, a violência que as pessoas cometem umas em relação às outras e a fugacidade de encontros superficiais.

Algumas observações preliminares sobre as cenas de Bausch aqui descritas, embora possam soar um tanto óbvias, são primordiais à reflexão pretendida. A primeira considera que no espetáculo em foco, cujas cenas de diferentes montagens se revelam através da linguagem do cinema, não haja somente dança, ou seja, as formas de dança que se apresentam são amalgamadas ao teatro e à performance. Outra observação importante é que as montagens, quando apresentam falas, diálogos e jogos de cena, remetem-se ao cotidiano, criam um espaço outro; e que esse cotidiano é, por sua vez, revelador de relações interindividuais, ações não abstratas, comportamentos humanos, colocados em relação direta com a forma de como o teatro representa a vida.

De acordo com a estudiosa Lícia Maria Moraes Sánchez (2010, p.53) “(...) a teatralidade bauschiana é construída pela sensibilidade de todos os envolvidos, para

CABRAL, Jeferson de Oliveira, SANTOS, Vera Lúcia Bertoni dos. Notas Sobre a Teatralidade na Dança-Teatro de Pina Bausch. Revista da FUNDARTE, Montenegro, p.19-31, ano 19, № 37, janeiro/Março.

Disponível em: http://.seer.fundarte.rs.gov.br/index.php/RevistadaFundarte/index> 30 de março de 2019. 


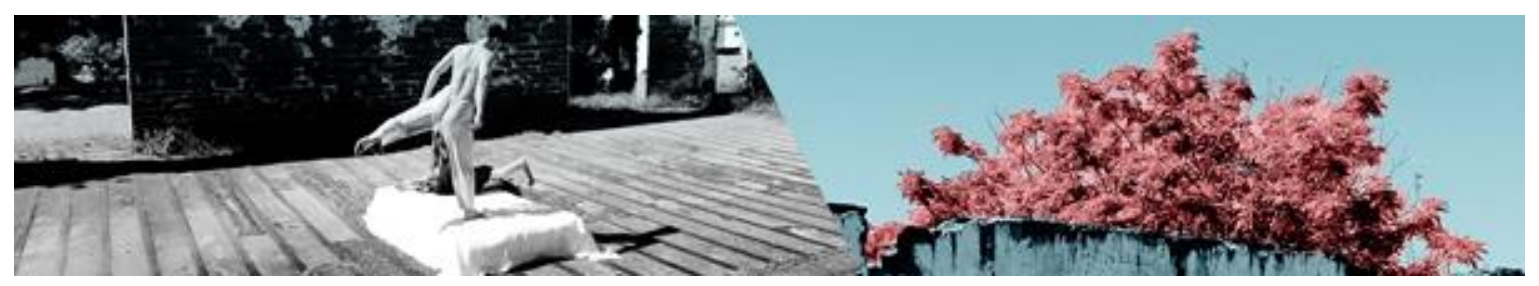

uma emissão e recepção sensíveis, sem intenções medidas". Considere-se, pois, que a arte da dança apresenta uma narrativa diferente da do teatro, pois é fundada na qualidade de movimentos e cria jogos cênicos distintos do teatro, que, por sua vez, constitui uma forma estética na qual a situação se processa de modo que o espaço e tempo outro possuem ligação próxima ao espectador.

Partindo do pressuposto que as considerações trazidas até aqui sejam suficientes para localizar o trabalho de Bausch numa zona de intersecção, de fricção, entre a dança e o teatro, para atribuir à coreógrafa funções de encenadora e para justificar a denominação binômia conferida à sua arte, arrisca-se a indagação: o que se considera especificamente teatral no espetáculo Kontakthof realizado por Bausch e seu grupo de dança-teatro?

Para objetivar a apreciação das cenas do espetáculo, foram escolhidos três momentos registrados nos documentários de Wenders (2011) e de Linsen e Roffman (2010). No primeiro registro, o cineasta une as três versões do espetáculo, correspondentes à montagem original, de 1978, realizada com os artistas do Wuppertal, e a outras duas montagens realizadas por Bausch, uma em 2002, com a colaboração de adultos não bailarinos acima de 65 anos, e outra, em 2008, com a colaboração de jovens não bailarinos. O outro registro é dedicado totalmente à montagem de 2008.

As cenas escolhidas são intituladas Assédio, do filme de 2011, Suicídio, do filme de 2010 e Venda de si mesmo; e a escolha foi motivada pela hipótese que os excertos trariam evidencias significativas de teatralidade.

A cena Assédio é composta por uma bailarina e nove bailarinos. Os espectadores são "convidados" a observar a ação, que acontece num grande salão, que remete aos salões de baile. A cor cinza, em tons diversos, predomina em todo o cenário, composto por dezenas de cadeiras pretas, um piano, microfones, um cavalo de parque de diversões e uma janela, que dá a ideia de passagem do dia, conforme incide a iluminação. Esses elementos contrastam diretamente com o colorido dos figurinos das mulheres.

O sentimento dominante na cena Assédio parece ser o de passividade, que se revela na figura de uma mulher de aparência delicada, que surge em cena

CABRAL, Jeferson de Oliveira, SANTOS, Vera Lúcia Bertoni dos. Notas Sobre a Teatralidade na Dança-Teatro de Pina Bausch. Revista da FUNDARTE, Montenegro, p.19-31, ano 19, № 37, janeiro/Março.

Disponível em: http://.seer.fundarte.rs.gov.br/index.php/RevistadaFundarte/index> 30 de março de 2019. 


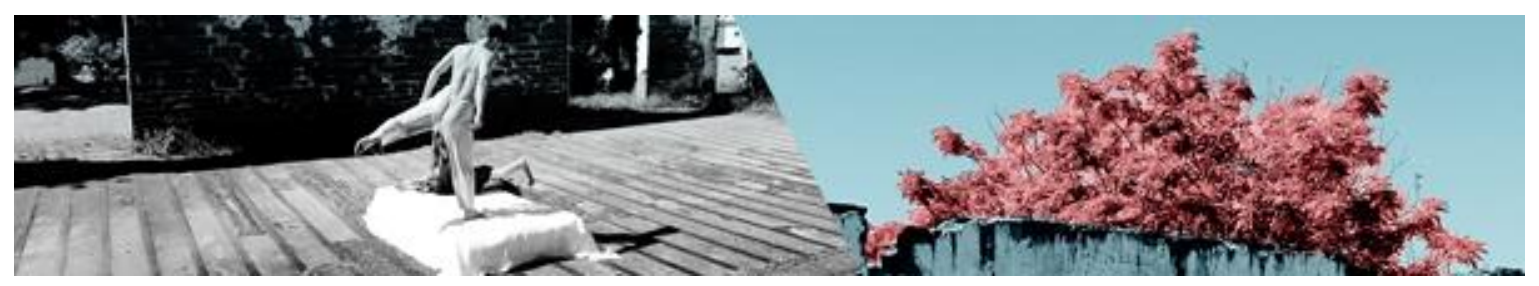

trajando um vestido cor de rosa de fino tecido, e cujo olhar cabisbaixo parece buscar conexão consigo mesmo. Esses elementos corroboram para o estabelecimento de uma das premissas da teatralidade: o chamado espaço outro. Não se vê no decorrer da cena qualquer movimento nitidamente dançado, o que cria outro tempo dentro da própria encenação, que se desenrola ao olhar do público imerso em silêncio. $\mathrm{Na}$ sequência, outra atmosfera instaura-se, caracterizando mais um elemento de teatralidade, a partir os corpos dos intérpretes, nove bailarinos-atores homens que entram em cena, um a um, como se buscassem algo que está no corpo da mulher. Assim começa uma procura baseada no assédio: os toques iniciais dos homens no corpo da mulher lembram carícias, primeiramente no seu rosto, a seguir nos seus cabelos, nos ombros, quando, num rompante, eles passam a beijá-la nos pulsos, no pescoço, até que se vê o corpo da mulher elevar-se no ar, erguido pelos homens, que a sustentam pela cintura. Os toques prosseguem e logo depois a mulher é posta no chão. Seu olhar ainda se encontra repousado, como se não pudesse fazer nada. Surge, então, outra bailarina que se desloca em cena sensualmente, trajando um vestido ajustado ao corpo. Assim que percebem a entrada da mulher, os homens voltam seus olhares a ela e passam a segui-la, deixando para trás o "objeto" do assédio anterior, em busca de outro objeto, passando a estabelecer nova relação de assédio.

A cena possibilita refletir sobre a intenção de ver e compreender o que está no palco a partir dos significados lançados como leitura e distinção de lugar, pois o público que assiste não pode agir em relação à violência sofrida, pois está colocado fora da ação. O excerto do filme mostra algo cotidiano elevado ao espetacular, possibilitando reconhecer a vida e refletir sobre ela a partir do corpo de outra pessoa. Assim, o espaço outro se revela vivo e a teatralidade, presente.

A cena Suicídio, mostrada no documentário de Linsen e Roffman, traz em cena uma cadeira e, próxima a ela, uma jovem, trajando um justo vestido cinza e uma echarpe lilás. A jovem sobe na cadeira e diz: "estou na beira do piano prestes a cair, mas antes de fazê-lo, grito alto para que todos escutem". O corpo da bailarinaatriz cria uma atmosfera intimista e a duplicidade do texto com a movimentação de cena reforça a teatralidade, pois o fato da jovem dizer que se encontra à beira de um 


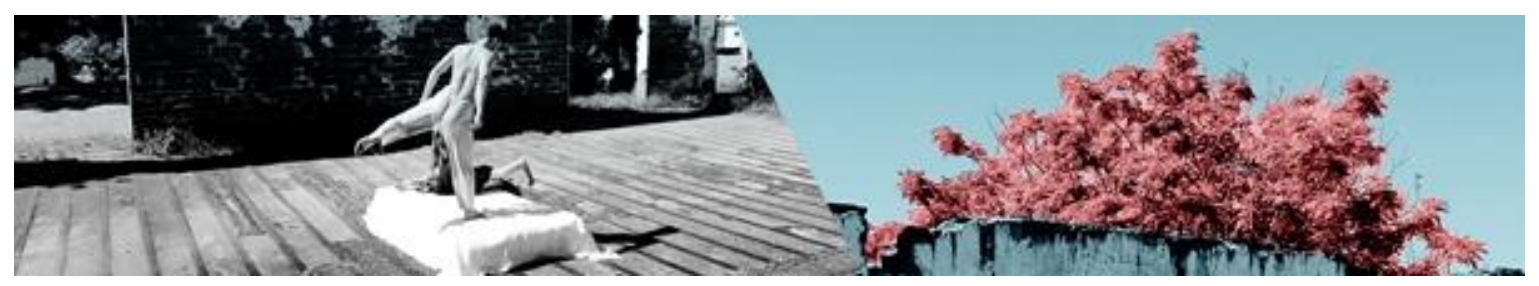

piano e estar, objetivamente, numa cadeira, leva o espectador a conectar-se com o seu imaginário, desprendendo-se da realidade apresentada em cena. A ação remete, pois, a outra espacialidade.

O estudo de Royd Climenhaga (2009) sobre Kontakthof aponta elementos teatrais por ele identificados ao assistir o espetáculo:

\begin{abstract}
Eu sou forçado a ver estas pessoas sob novas condições. Isto é um momento de distanciamento brechtiano levado ao extremo, como um lance para que a cena mostre nossa própria distância da vida. Os atoresbailarinos criam um mundo no palco por meio da combinação de sua presença e da metáfora de nos contarem algo. (CLIMENHAGA, 2009, p. 89) (tradução nossa) ${ }^{6}$.
\end{abstract}

Essa forma de compreender o espetáculo relaciona-se aos pressupostos de Féral acerca do poder do ator de transformar os elementos que o cercam em signo. A cena Suicídio é exemplar nesse sentido, na medida em que a ficção é posta como convenção e o espectador, embora acredite naquilo que é dito, aceita o desafio proposto por sua própria percepção, que o leva a um lugar lúdico, entre o real e o ficcional.

As ideias de Féral (2004) sobre o acontecimento que se situa fora de si, criando o espectador e a cena em sua relação de alteridade, inspiram a pensar a poética de Bausch, na qual os espectadores se reconhecem no palco, longe da ação, mas a vivenciando e transformando em teatral suas próprias relações consigo mesmo, com o outro e com a sociedade, através do espaço outro do seu imaginário.

A última cena, intitulada Venda de si mesmo, é um excerto do filme de Wenders, que envolve todos os membros do elenco em caminhadas que partem de diferentes pontos do palco e dirigem-se ao proscênio, culminando na exposição de partes do corpo pelos bailarinos-atores. Uns caminham, enquanto outros permanecem sentados, até chegar o momento de levantar e andar. No constante ir e vir dos intérpretes, a teatralidade é marcada pela força impressa pelos corpos a cada passo, a cada parada, a cada momento em que expõem diferentes partes dos

\footnotetext{
${ }^{6}$ No original: I am forced to see these people under new conditions. It is a moment of Brecht alienation taken to the extreme and shot through the piece as an overriding metaphor for our own
}

CABRAL, Jeferson de Oliveira, SANTOS, Vera Lúcia Bertoni dos. Notas Sobre a Teatralidade na Dança-Teatro de Pina Bausch. Revista da FUNDARTE, Montenegro, p.19-31, ano 19, № 37, janeiro/Março.

Disponível em: http://.seer.fundarte.rs.gov.br/index.php/RevistadaFundarte/index> 30 de março de 2019. 


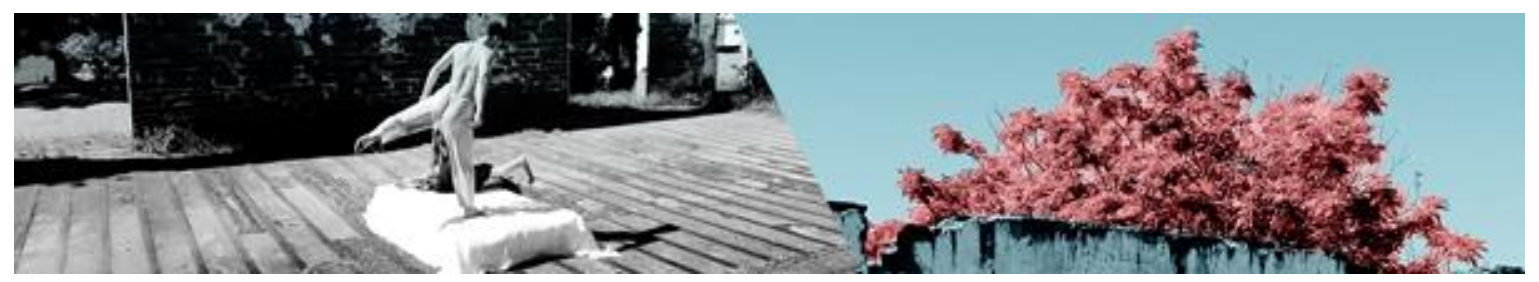

seus corpos, remetendo a diversos significados. Novamente não se observa qualquer movimento nitidamente dançado: cada caminhada é norteada por um objetivo preciso e, após seu término, se iniciam novos momentos que invocam situações cotidianas, teatralizadas.

Em determinada passagem do documentário, Bausch menciona as motivações para a criação da cena, que, segundo ela, surgem da necessidade de expressar os sentimentos referentes a momentos vividos por bailarinos em audições para companhias de dança, prática frequente na sua atividade artística. A exposição relatada por Bausch reporta nitidamente a uma venda de si mesmo, pois diz respeito a estratégias usadas pelo bailarino para tornar-se atrativo em cena: os dentes são mostrados, também a forma das mãos e o corpo, em diferentes partes, de distintos os pontos de vista.

Climenhaga (2009, p.78) aponta especificidades dessa cena e do trabalho de Bausch como um todo: "Kontakthof usa técnicas teatrais como metáfora para uma ideia geral do espetáculo em conexão com nossas relações sociais. Simples e dramaticamente, as cenas são reconhecidas como teatrais"7.

O trabalho de Bausch junto ao Wuppertal Tanztheater caracteriza-se por retratar momentos de vida do ser humano. As cenas dos seus espetáculos são criadas a partir do entendimento da coreógrafa e encenadora e do seu elenco de bailarinos-atores sobre suas próprias vivências, que são transformadas, corporificadas, dançadas, teatralizadas, performadas, poetizadas, gerando movimentos, gestos, palavras, ações, num laborioso processo de criação estética. As reflexões sobre o legado de Bausch a partir das lentes de Wenders, Linsen e Roffman e de contribuições do campo dos estudos teatrais permitem afirmar que a teatralidade de Kontakthof reside no fato de conferir espetacularidade a momentos cotidianos, triviais, e de evidenciar, poeticamente, contatos sociais estabelecidos em diferentes formas de interação humana. Assim, é a vida posta em cena no teatro de Pina Bausch.

distance from life. The performers create the world on stage through a combination of actual presence and metaphor rather than telling us something.

CABRAL, Jeferson de Oliveira, SANTOS, Vera Lúcia Bertoni dos. Notas Sobre a Teatralidade na Dança-Teatro de Pina Bausch. Revista da FUNDARTE, Montenegro, p.19-31, ano 19, № 37, janeiro/Março.

Disponível em: http://.seer.fundarte.rs.gov.br/index.php/RevistadaFundarte/index> 30 de março de 2019. 


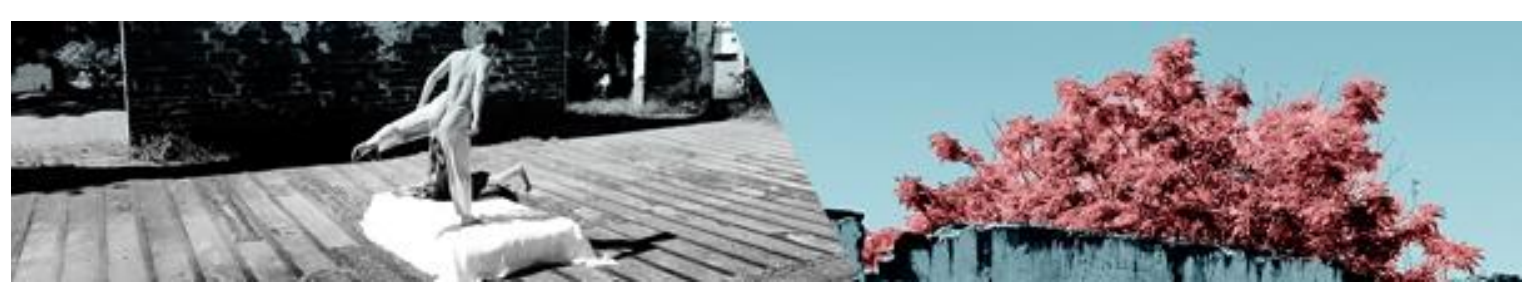

\section{Referências:}

BENTIVOGLIO, Leonetta. O teatro de Pina Bausch. Lisboa: Lito Tejo,1994.

CLIMENHAGA, Royd. Pina Bausch. New York: Routledge, 2009.

FÉRAL, Josette. La teatralidad: en busca de la especificidad del lenguaje teatral. In: Teatro, teoría y práctica: más allá de las fronteras. Buenos Aires: Gallerna, 2004.

FERÁL, Josette. Por uma poética da performatividade. Sala Preta, São Paulo, v.8, p.197-210, 2008.

FERNANDES, Silvia. Teatralidades Contemporâneas. In: Teatralidades Contemporâneas. São Paulo: Perspectiva, 2010.

GÁLHOS, Cláudia. Pina Bausch - sentir mais. Lisboa: D.Quixote, 2010.

PAVIS, Patrice. Dicionário de teatro. São Paulo: Perspectiva, 1999.

PINA. Direção: Wim Wenders. Nue Road Movies Berlin, Alemanha, 2010. 100 min, 3D digital.

SÁNCHEZ, Lícia Maria Moraes. A dramaturgia da memória no teatro-dança. São Paulo: Perspectiva, 2010.

SONHOS EM MOVIMENTO. Anne Linsel e Rainer Hoffman: Imovision, Berlim, 2010, $89 \mathrm{~min}$.

\footnotetext{
7 Kontakthof uses techniques of theatrical presentation as metaphors for the general idea of presentation and connection in our social relationship. Simply and dramatically the act of presentation in the theatre (tradução nossa).
}

CABRAL, Jeferson de Oliveira, SANTOS, Vera Lúcia Bertoni dos. Notas Sobre a Teatralidade na Dança-Teatro de Pina Bausch. Revista da FUNDARTE, Montenegro, p.19-31, ano 19, no 37, janeiro/Março.

Disponível em: http://.seer.fundarte.rs.gov.br/index.php/RevistadaFundarte/index> 30 de março de 2019. 